\title{
Little Adjustment of Lowry and Biuret Methods to Get Better Absorbance of Proteins
}

\author{
Yohannis Wondwosen ${ }^{1 *}$, Sisay Addisu ${ }^{1}$, Tsehayneh Kelemu ${ }^{1}$, Maria Degef ${ }^{1}$ and Gashaw Tadele ${ }^{2}$ \\ ${ }^{1}$ Department of Medical Biochemistry, College of Health Sciences, Addis Ababa University, Addis Ababa, Ethiopia \\ ${ }^{2}$ Department of Chemistry, College of Natural and Computational Sciences, Mizan Tepi University, Ethiopia
}

*Corresponding author: Yohannis Wondwosen, Department of Medical Biochemistry, College of Health Sciences, Addis Ababa

University, Addis Ababa, Ethiopia

\section{ARTICLE INFO}

Received: 慧 October 27, 2021

Published: 幽 November 10, 2021

Citation: Yohannis Wondwosen, Sisay Addisu, Tsehayneh Kelemu, Maria Degef, Gashaw Tadele. Little Adjustment of Lowry and Biuret Methods to Get Better Absorbance of Proteins. Biomed J Sci \& Tech Res 39(5)-2021. BJSTR. MS.ID.006367.

Keywords: Copper Nitrate; BSA; Interference; Lowry Method; Biuret Method; DOC-TCA

\begin{abstract}
Copper sulfate has been staying as a major source of $\mathrm{Cu}^{2+}$ for copper based colorimetric protein determinations. Hemi-penta hydrated Copper nitrate furnish $\mathrm{Cu}^{2+}$ ions which can be used as an alternative to Penta hydrated Copper sulfate in Copper based colorimetric protein determinations. We describe herein the development of a new modified Lowry and Biuret procedures which replace penta-hydrated Copper sulfate of the original reagents $\left(\mathrm{Cu} \mathrm{SO}_{4} .5 \mathrm{H}_{2} \mathrm{O}\right)$ by hemi penta-hydrated Copper nitrate $\left(\mathrm{Cu}_{2}\left(\mathrm{NO}_{3}\right)_{2} 2.5 \mathrm{H}_{2} \mathrm{O}\right)$. Those methods were applied for measuring different standard samples of protein. We favorably compared the modified methods with the original Lowry and Biuret methods for reliability, assay time and resistance by interferences of non-proteinaceous compounds. Those modified methods showed better reliability, rapid assay time of color development and strong resistance of interfering substances. The modified procedures might be applicable as better options for the determination of protein in a biological sample.
\end{abstract}

\section{Introduction}

Proteins are the most abundant macromolecules in a biological system and their accurate quantification is an important part of any biochemical investigation in life sciences [1]. Many colorimetric dye-based methods are avilable for the measurment of protein concentration in solutions [2-4]. Out of those the most popular methods include Lowry [5-7], Biuret [8], Bradford [9] and Bicinconic acid [10]. However each of these methods has its own pros and cons with respect to sensitivity, reproducibility, rapidity and level of interference by non-protinaceous substances. For instance, deteregents interfere in the Bradford method [11], while chelating agents [12], Magnesium and Calceuim ions [13,14] and disulfite reagents [15] interfere in Lowry's method. Bicinconic acid method is susceptible for inhibition by thiols,lipids and reducing sugars $[16,17]$. Levels of interference are least in the Biuret method however its capacity to detect proteins at lower concentration is less in comparison with other assays [18]. Out of several methods designed for estemation of proteins, Lowry's assay ranks as the most higly sited method due to its simplicity and ability to detect proteins even in microgram conentrations [19]. Based on an uprising need to design a facile analytical procedure for protein estimation, various modifications have been made. Moreover, the expanding number of colorimetric assays for the quantitation of proteins has proceeded upgrade in accuracy and sensitivity with the onset of modern techniques. From DOC-TCA (DeoxycholateTricarboxylic acid) precipitation for avoiding interferences to comparison of separate methods for measuring specific standards were highly performed [20,21].

Recent modifications designed more sensitive methods to detect proteins even in Nano gram concentrations [22]. Although most of the modifications are focused to increase rapidity, sensitivity 
and resistance to interfering substances, limited modifications try to modify measuring validity of the assay for numerous types of proteins. We suspected that possible replacement of $\mathrm{Cu} \mathrm{SO}_{4} \cdot 5 \mathrm{H}_{2} \mathrm{O}$ of the $\mathrm{Cu}^{2+}$ based colorimetric protein determinations by $\mathrm{Cu}_{2}\left(\mathrm{NO}_{3}\right)_{2}$ $2.5 \mathrm{H}_{2} \mathrm{O}$ might advent a method that has better improvements. Relied on a difference in chemical and physical properties (Table 1), equal amounts of the two copper sources have caused varying activation on plant root-based peroxidases $[23,24]$. Those differences attracted our intension to perform and compare the dyebased methods inclusive of those chemicals. Among the mentioned four methods, we selected Biuret and Lowry procedures situated on better resistance to interfering substances and sensitivity respectively. Here we show the modified methods of Biuret and

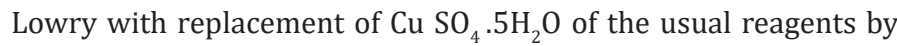
$\mathrm{Cu}_{2}\left(\mathrm{NO}_{3}\right)_{2} 2.5 \mathrm{H}_{2} \mathrm{O}$ followed with testing of the modified methods for estimation of different standards including BSA, catalase, egg albumin and gelatin. Comparison of the new methods with the well-known procedures was conducted based on reliability, assay time and resistance to selected interfering substances (SDS, Tris buffer, Sodium sulfite, Cadmium sulfate, Cobaltous acetate, Sodium chromate and Tannic acid). DOC-TCA precipitation [7] was performed to eliminate recorded interferences from the nonproteinic substances and results are compared before and after the precipitation. Suitable wavelength scan of the new methods was also performed in between a range of 500-700 nm.

Table 1: Physical and chemical properties of Copper (II) Nitrate and Copper (II) sulfate.

\begin{tabular}{|c|c|c|}
\hline & $\begin{array}{c}\text { Copper (II) Nitrate } \\
\text { Hemi Penta Hydrate }\end{array}$ & $\begin{array}{c}\text { Copper (II) Sulfate } \\
\text { Penta Hydrate }\end{array}$ \\
\hline Compound formula & $\mathrm{Cu}_{2}\left(\mathrm{NO}_{3}\right)_{2} 2.5 \mathrm{H}_{2} \mathrm{O}$ & $\mathrm{Cu} \mathrm{SO}_{4} .5 \mathrm{H}_{2} \mathrm{O}$ \\
\hline Molecular weight & $465.188 \mathrm{~g} / \mathrm{mol}$ & $248.68 \mathrm{~g} / \mathrm{mol}$ \\
\hline Appearance & Crystalline lumps & Crystalline solid \\
\hline Melting point & $115^{\circ} \mathrm{C}$ & $110{ }^{\circ} \mathrm{C}$ \\
\hline Density & $2.32 \mathrm{~g} / \mathrm{cm}^{3}$ & $2.284 \mathrm{~g} / \mathrm{cm}^{3}$ \\
\hline Solubility in water & Best & Best \\
\hline Exact mass & 463.86329 & 248.93415 \\
\hline Mono isotopic mass & 463.86 & 248.93 \\
\hline Color & Light blue & Deep blue \\
\hline
\end{tabular}

\section{Materials and Methods}

Reagents and chemicals were obtained from the following sources: Egg albumin, Bovine Serum Albumin(BSA), FC reagent, Sodium carbonate, Gelatin powder, Potassium sodium tartrate, Casein, Cobaltous acetate, Cadmium sulfate, Sodium di chromate and Deoxycholate were obtained from British Drug House(BDH) British; Tri Carboxylic Acid(TCA) was obtained from May and Baker Company, England; Sodium Hydroxide was obtained from Fisher Scientific, United Kingdom; FC reagent was obtained from MERCK company, Germany; Tris Hydrochloride and Cupric Acetate were obtained from Labort Finch Chemical, India. Penta hydrated Cupric Sulfate was obtained from Osaka Hayashi pure Chemical Industries, Japan; Hemi Penta hydrated Copper nitrate, Sodium Sulfite, Sodium Dodecyl Sulfate (SDS) and Tannic acid were obtained from Sigma Aldrich, Chemicals, St. Louis, Missouri, USA.

\section{Protein Estimation by the Standard and Modified Methods}

Standard protein estimation was performed by Lowry's method according to Lowry et al. [5] within a linear range of $0-75 \mu \mathrm{g} / \mathrm{ml}$, Biuret's method as reported by Gornall et al. [8] within a linear range of $1-5 \mathrm{mg} / \mathrm{ml}$. Reagents for the modified Lowry and Biuret methods were prepared with substitution of $\mathrm{Cu}$. $\mathrm{SO}_{4} 5 \mathrm{H}_{2} \mathrm{O}$ of the original reagents by $\mathrm{Cu}_{2}\left(\mathrm{NO}_{3}\right)_{2} 2.5 \mathrm{H}_{2} \mathrm{O}$. Briefly, modified Lowry's reagent was prepared by mixing $2 \% \mathrm{w} / \mathrm{v}$ of $1 \mathrm{ml} \mathrm{Cu}_{2}\left(\mathrm{NO}_{3}\right)_{2} 2.5 \mathrm{H}_{2} \mathrm{O}$, $2 \% \mathrm{w} / \mathrm{v}$ of $1 \mathrm{ml}$ Sodium potassium $\left(\mathrm{Na}^{+} \mathrm{K}^{+}\right)$tartrate and $4 \% \mathrm{w} / \mathrm{v}$ of $98 \mathrm{ml}$ Sodium Carbonate. Modified Biuret reagent was prepared according to Gornall et al. [8] except for substitution of Penta hydrated $\mathrm{Cu} \mathrm{SO}_{4} .5 \mathrm{H}_{2} \mathrm{O}$ of the standard by hemi penta-hydrated $\mathrm{Cu}_{2}$ $\left(\mathrm{NO}_{3}\right)_{2} 2.5 \mathrm{H}_{2} \mathrm{O}$ Briefly, $1.5 \mathrm{~g}$ of $\mathrm{Cu}_{2}\left(\mathrm{NO}_{3}\right)_{2} 2.5 \mathrm{H}_{2} \mathrm{O}$ and $6 \mathrm{~g}$ of Sodium potassium $\left(\mathrm{Na}^{+} \mathrm{K}^{+}\right)$tartrate were dissolved in $500 \mathrm{ml}$ of water. While stirring the mixture, $300 \mathrm{ml}$ of $10 \% \mathrm{w} / \mathrm{v}$ Sodium Hydroxide was added to it. Finally, $200 \mathrm{ml}$ of deionized water was added and the mixture was kept for use.

\section{Effect of Interfering Substances}

Effect of interfering substances both in the standard and modified Lowry and Biuret methods was performed according to Brown et al. [17]. Interfering agents such as Tannic acid(0$20 \mathrm{mM})$, Sodium sulfite $(0-1 \mathrm{mM})$, Tris buffer(0-0.5M), Sodium Dodecyl Sulfate/SDS(0-1Mm), Cadmium sulfate(0-1mM), Sodium chromate $(0-1 \mathrm{mM})$ and Cobaltous acetate $(0-1 \mathrm{mM})$ were checked for their effect on absorbance measurements.

\section{Effect of Interference on Lowry and Modified Lowry Methods}

On mixture of $0.5 \mathrm{ml}$ of interfering substance and $0.5 \mathrm{ml}(35 \mu \mathrm{g} /$ $\mathrm{ml}$ ) of BSA, $3 \mathrm{ml}$ of the reagent was added. While standing 30 minutes for the standard method, mixture was allowed to stand 23 minutes for the modified method. $0.5 \mathrm{ml}$ of $1: 1$ diluted FC reagent was added and mixtures allowed to stand additional 10 minutes. Finally, the absorption was measured at 670nm (Figure 1).

\section{Effect of Interference on Biuret and Modified Biuret Methods}

On mixture of $0.5 \mathrm{ml}$ of interfering substance and $0.5 \mathrm{ml}$ $(1.5 \mathrm{mg} / \mathrm{ml})$ of BSA, $3 \mathrm{ml}$ of the reagent was added. While standing 30 minutes for the standard method, mixture was allowed to stand 23 minutes for the modified method. Finally, the absorption was measured at $570 \mathrm{~nm}$ (Figure 1). 


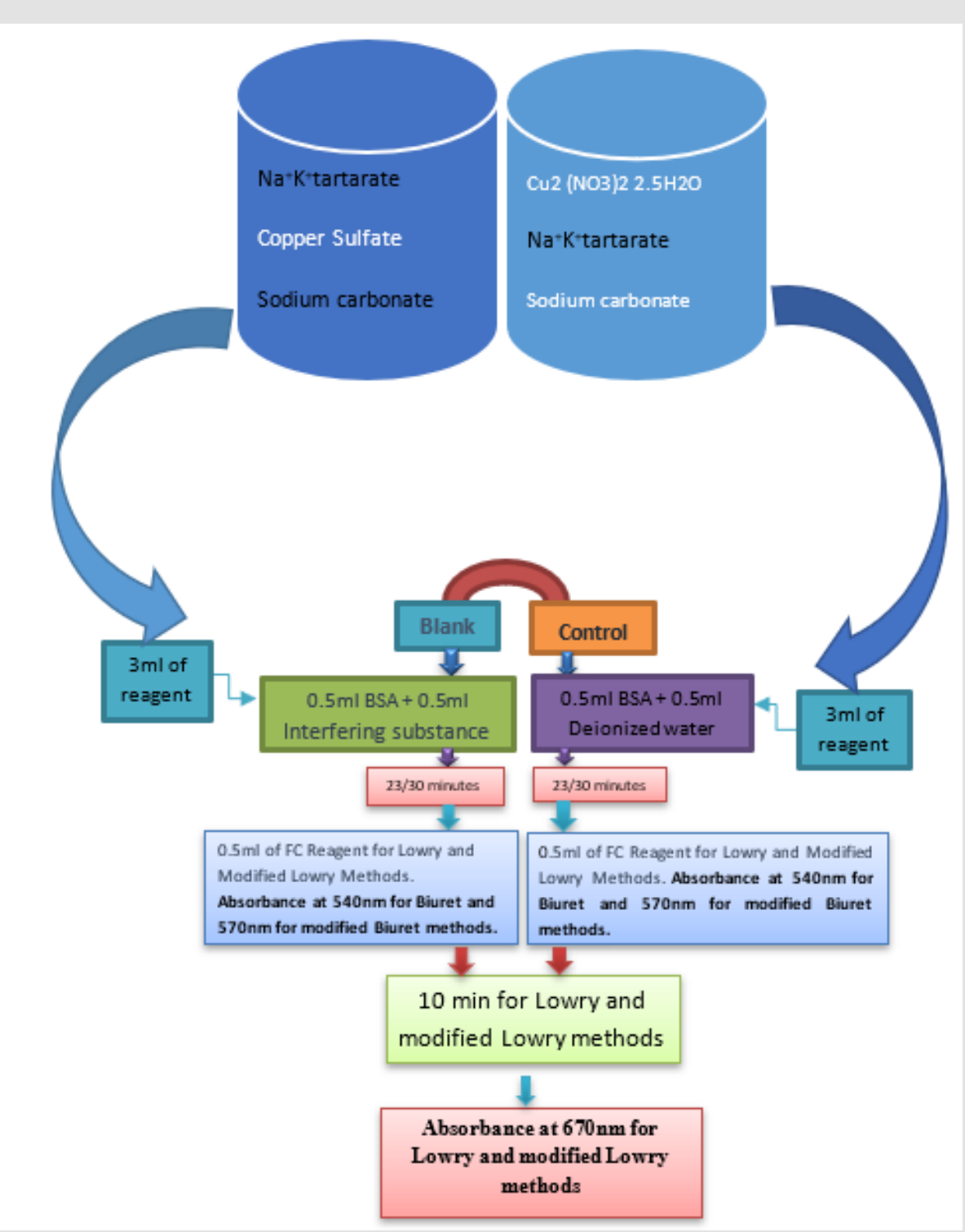

Figure 1: Procedure for the effect of interfering substances on the absorbance measurement by standard and modified Lowry and Biuret methods.

\section{Concentration of Copper in the Original and Modified Reagents}

As per the ratio given by Lowry et al. [5], concentration of $\mathrm{Cu}^{2+}$ ion in the original Lowry reagent was $80.42 \mathrm{mM}$. With replacement of Copper source by Copper nitrate, concentration of $\mathrm{Cu}^{2+}$ in the modified Lowry reagent was $42.99 \mathrm{mM}$. Based on the ratio described by Gornal et al. [8], concentration of $\mathrm{Cu}^{2+}$ ion in the original Biuret reagent was $60.318 \mathrm{Mm}$. While replaced Copper source by Copper nitrate, concentration of $\mathrm{Cu}^{2+}$ in the modified Biuret reagent was $32.24 \mathrm{mM}$.

\section{DOC-TCA Precipitation}

Based on recorded reliable interferences, DOC-TCA precipitation was conducted for the recovery of protein sample
(BSA). The procedure was performed according to Peterson [7]. Briefly: mixture of $0.5 \mathrm{ml}$ of interfering substance and $0.5 \mathrm{ml}$ of BSA was centrifuged at $4800 \mathrm{~g}$ for $10 \mathrm{~min}$. With safe decantation of the supernatant, the pellet was kept for performing standard and modified measurements of it as per the description of Peterson [7]. Absorbance results were recorded and compared before and after precipitation.

\section{Suitable Wave-Length Scan of the New Methods}

Suitable wavelength scan was conducted for identifying best wavelength of both modified Lowry and Biuret methods. The scan was done by measuring absorbance of standard protein samples in at a wave length range of 500 to $700 \mathrm{~nm}$. 


\section{Absorbance Measurement}

Absorbance measurement of protein samples was performed by using Jenway 67 series spectrophotometer in the main laboratory of Department of Biochemistry, College of Health Sciences, and Addis Ababa University. All results were expressed in terms of Mean \pm Standard Deviation.

\section{Reliability of the Assay}

Reliability of the modified assays was determined by variation of absorbance results between $24 \mathrm{hrs}$ /a day and between $168 \mathrm{hrs} /$ a week as per described by Pretty et al. [2,22,23]. Briefly, after the first absorbance measurement samples were kept at room temperature for $24 \mathrm{hrs}$ followed with the second absorbance measurement to determine a day coefficient of variation. Weekly coefficient of variation was also performed with the same procedure except keeping of the samples at a room temperature for a week. Reliability was expressed in terms of percent coefficient of variation. Comparison of coefficient of variation between the standard and modified methods was also performed.

\section{Results and Discussion}

The first step for methodological approval of the modified methods was checking linearity of the standard sample (BSA) absorbance measurement at a different wavelength. After measuremental approval of both the modified Lowry (Figure 2A) and Biuret (Figure 2B) methods, the best linearity wavelength selection was followed. In both the methods, scan for selection was conducted at a wavelength rage of 500 to $700 \mathrm{~nm}$ with a gap of $30 \mathrm{~nm}$ in between (Figure 2). Though the modified Lowry method has shown a linearity in the selected wavelength ranges (Figure $5 \mathrm{~A}_{2}$ ), the best curve of accuracy was recorded at $670 \mathrm{~nm}$ with a similar wavelength to the original Lowry method [5]. To the nearest wavelength from the original Biuret method [8], the modified Biuret method has shown precise linearity at a wavelength of $570 \mathrm{~nm}$. Those observations confirm as the modified methods have validity to measure the standard protein at a specified wavelength. On the basis, tests remain to perform were conducted at $670 \mathrm{~nm}$ for the modified Lowry method and at $570 \mathrm{~nm}$ for the modified Biuret method. Rather than measuring concentration of BSA, validity of the new methods to measure different standard protein samples was performed with casein, gelatin and egg albumin (Figure 3 ). Both the modified methods manifest more linear curves for absorbance of the protein samples (Figure 3B \& 3D). Since one of the ways using for demonstration of validity is testing consistency of the method for measurement of various standard samples, both our modified Lowry and Biuret assays displayed consistency with linear measurements of the mentioned standard proteins.

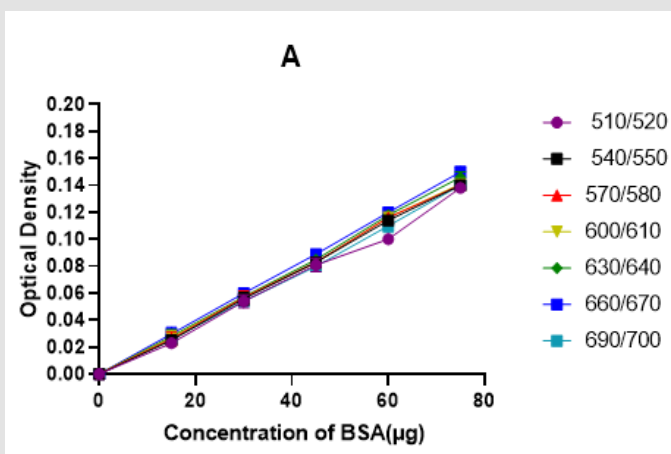

B

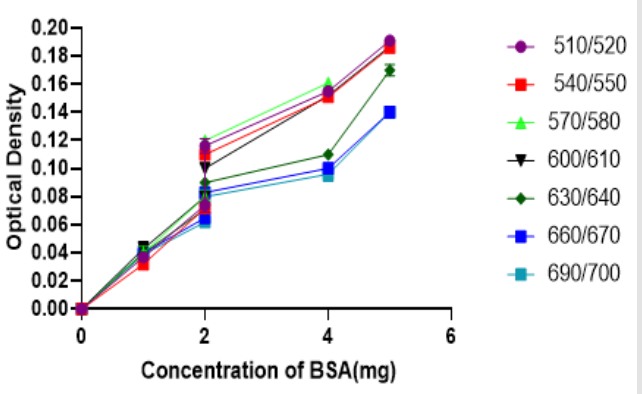

Figure 2: Scan for selection of best linearity wavelength for the modified Lowry (A) and Biuret (B) methods.

Comparison with the original methods on the basis of standard measurements (Figure 3E \& 3F) was also performed and the modified methods have shown similar consistency of measurements with the original methods (Figure 3A \& 3B). Recent modifications $[2,22,25,26]$ for the original protein estimation methods were focused on improving lower limit of detection (sensitivity), resistance to ionic compounds and reproducibility of the assay. We employed Copper nitrate-based modification of Lowry and Biuret methods for developing a little adjusted procedure showing better or comparable resistance of the interfering substances such as Tannic acid, Sodium sulfite, Tris buffer, Cobaltous acetate, SDS, Sodium chromate and Cadmium sulfate (Table 2). Some of the interfering substances resulted in a decline of absorbance including negative readings with significant formation of precipitates while others upraised absorbance to provide unreliable results. As clearly shown in Table 2, as low as $15 \mu \mathrm{M}$ of tannic acid was resulted to unreliable rise of absorbance reading for both the original (Figure 4) and modified Lowry and Biuret methods. Similar results on the Lowry method were reported by Xie et al. [27]. While elevating the absorbance reading for original and modified Lowry methods, as low as $0.3 \mathrm{mM}$ of Sodium sulfite did not affect Biuret and modified Biuret methods. Effect of sulfites on the Lowry method was also reported [28]. Although, $0.1 \mathrm{M}$ of tris buffer was deviated to over estimation of protein in Biuret and modified Biuret methods, it leaded to decline of absorbance reading for Lowry and modified Lowry methods. As low as $0.2 \mathrm{mM}$ of Sodium chromate, Cobaltous 
acetate and Cadmium sulfate were resulted for the declined the modified Lowry, original and modified Biuret methods (Table negative absorbance with a precipitate formation on the original 2).

Lowry method. However, they did not show any significant effect on
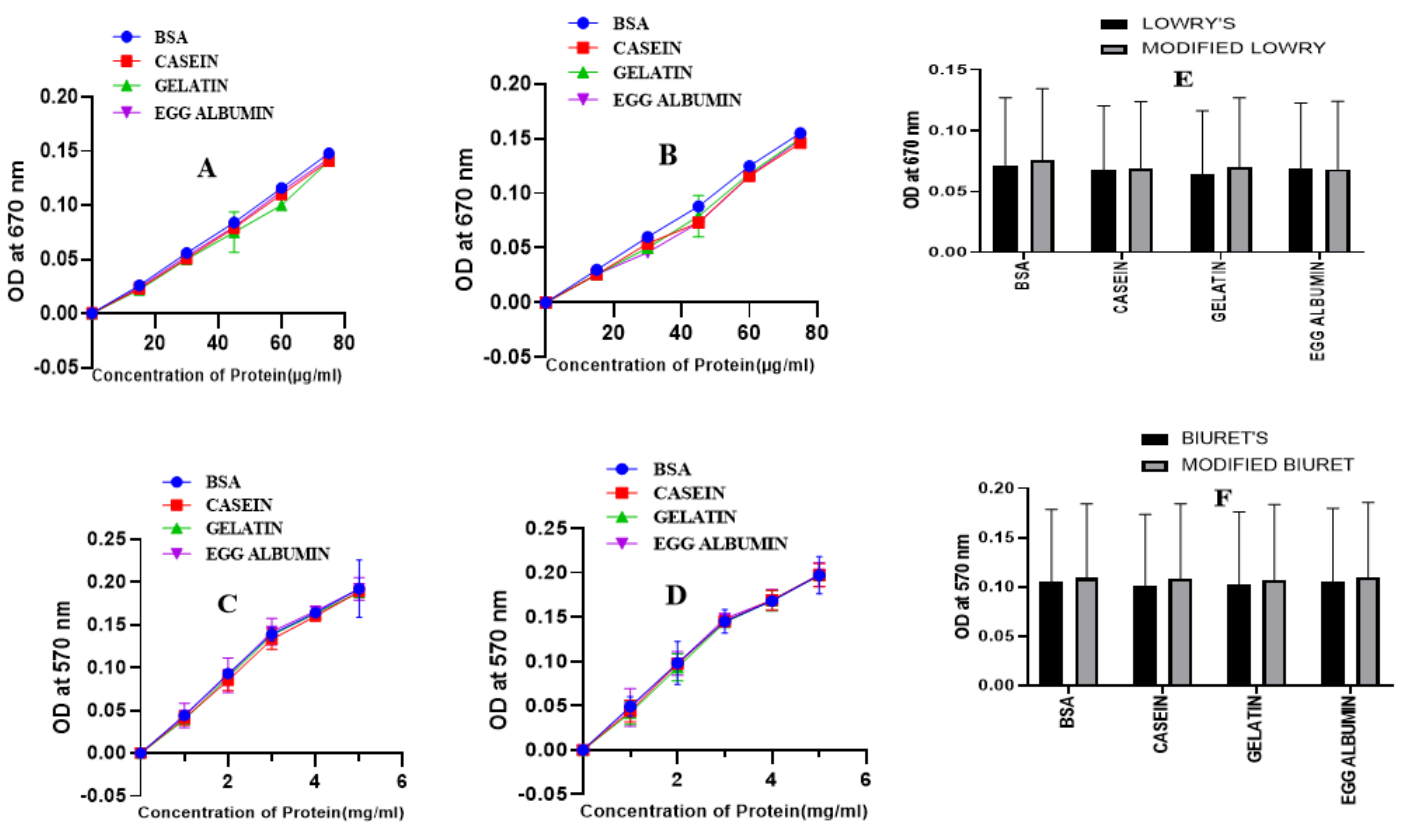

Figure 3: Standard curves of protein samples analyzed by Lowry's method (A), modified Lowry method (B), Biuret's method(C) and modified Biuret method (D). Comparison of Lowry and modified Lowry (F), Biuret and modified Biuret $(\mathrm{G})$ methods for the measurement of standard proteins.
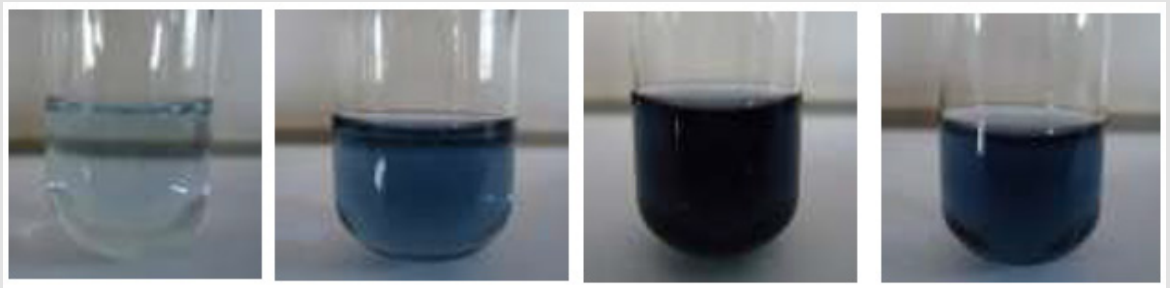

Figure 4: Photographs of BSA alone and BSA +tannic acid solutions prepared by Lowry procedure. The deep blue color development in the tannic acid concentration dependent manner; lane 1, BSA alone, lanes 2-4, 15, 20, and $25 \mu \mathrm{m}$ of tannic acid mixed with BSA, respectively.

Table 2: Effect of different concentrations of interfering substances on the optical density measurement by Lowry, modified Lowry, Biuret and modified Biuret methods. Interferences are identified for $35 \mu \mathrm{g}$ of BSA in Lowry and modified Lowry methods while for $1.5 \mathrm{mg}$ of BSA in Biuret and modified Biuret methods.

\begin{tabular}{|c|c|c|c|c|c|c|}
\hline $\begin{array}{c}\text { Protein } \\
\text { sample }\end{array}$ & $\begin{array}{c}\text { Interfering } \\
\text { substance }\end{array}$ & $\begin{array}{c}\text { Concentration } \\
\text { of interfering } \\
\text { substance }\end{array}$ & $\begin{array}{c}\text { Lowry method } \\
\text { (Copper sulfate) } \\
\mathbf{6 7 0 n m}\end{array}$ & $\begin{array}{c}\text { Lowery method } \\
\text { (Copper nitrate) } \\
\mathbf{6 7 0 n m}\end{array}$ & $\begin{array}{c}\text { Biuret method } \\
\text { (Copper sulfate) } \\
\mathbf{5 7 0 n m}\end{array}$ & $\begin{array}{c}\text { Biuret method } \\
\text { (Copper nitrate) } \\
\mathbf{5 7 0 n m}\end{array}$ \\
\hline BSA & + Tannic acid & $\mathbf{0 . 0 \mu M}$ & $\mathbf{0 . 0 6 9} \pm \mathbf{0 . 0 0 1 5 3}$ & $\mathbf{0 . 0 6 9 \pm 0 . 0 0 5 7}$ & $\mathbf{0 . 0 7 9 \pm 0 . 0 0 0 5}$ & $\mathbf{0 . 0 7 9} \pm \mathbf{0 . 0 0 0 5}$ \\
\hline & & $5.0 \mu \mathrm{M}$ & $0.07 \pm 0.00115$ & $0.069 \pm 0.0037$ & $0.08 \pm 0.0005$ & $0.079 \pm 0.0005$ \\
\hline & & $10 \mu \mathrm{M}$ & $0.071 \pm 0.0005$ & $0.069 \pm 0.0041$ & $0.08 \pm 0.011$ & $0.084 \pm 0.0001$ \\
\hline & & $15 \mu \mathrm{M}$ & $0.26 \pm 0.01$ & $0.19 \pm 0.015$ & $0.11 \pm 0.01$ & $0.092 \pm 0.0001$ \\
\hline & & $20 \mu \mathrm{M}$ & $0.51 \pm 0.01$ & $0.41 \pm 0.01$ & $0.11 \pm 0.01$ & $0.098 \pm 0.0001$ \\
\hline & +Sodium sulfite & $\mathbf{0 . 0} \mathbf{m M}$ & $\mathbf{0 . 0 6 9} \pm \mathbf{0 . 0 0 1 5 3}$ & $\mathbf{0 . 0 6 9} \pm \mathbf{0 . 0 0 0 5}$ & $\mathbf{0 . 0 7 9} \pm \mathbf{0 . 0 0 0 5}$ & $\mathbf{0 . 0 7 9} \pm \mathbf{0 . 0 0 0 5}$ \\
\hline & & $1 \mathrm{mM}$ & $0.071 \pm 0.001$ & $0.07 \pm 0.0005$ & $0.079 \pm 0.0005$ & $0.08 \pm 0.00$ \\
\hline & & $2 \mathrm{mM}$ & $0.12 \pm 0.01$ & $0.097 \pm 0.001$ & $0.079 \pm 0.0005$ & $0.08 \pm 0.00$ \\
\hline
\end{tabular}




\begin{tabular}{|c|c|c|c|c|c|}
\hline & $3 \mathrm{mM}$ & $0.198 \pm 0.001$ & $0.164 \pm 0.0015$ & $0.079 \pm 0.0005$ & $0.08 \pm 0.00$ \\
\hline & $4 \mathrm{mM}$ & $0.199 \pm 0.0005$ & $0.171 \pm 0005$ & $0.08 \pm 0.00$ & $0.08 \pm 0.00$ \\
\hline & $10 \mathrm{mM}$ & $2.497 \pm 0.001$ & $2.15 \pm 0.01$ & $0.08 \pm 0.00$ & $0.08 \pm 0.00$ \\
\hline +Tris Buffer & $0.0 \mathrm{M}$ & $0.069 \pm 0.00153$ & $0.069 \pm 0.0005$ & $0.079 \pm 0.0005$ & $0.079 \pm 0.0005$ \\
\hline & $0.1 \mathrm{M}$ & $0.063 \pm 0.0015$ & $0.067 \pm 0.0005$ & $0.10 \pm 0.0015$ & $0.082 \pm 0.0009$ \\
\hline & $0.2 \mathrm{M}$ & $0.061 \pm 0.00095$ & $0.064 \pm 0.0005$ & $0.10 \pm 0.00095$ & $0.0880 \pm 0.0005$ \\
\hline & $0.3 \mathrm{M}$ & $0.05 \pm 0.0032$ & $0.058 \pm 0.0005$ & $0.10 \pm 0.00055$ & $0.0930 \pm 0.0009$ \\
\hline & $0.4 \mathrm{M}$ & $0.041 \pm 0.001$ & $0.049 \pm 0.0005$ & $0.10 \pm 0.0005$ & $0.099 \pm 0.0005$ \\
\hline & $0.5 \mathrm{M}$ & $0.033 \pm 0.0019$ & $0.048 \pm 0.0005$ & $0.10 \pm 0.0005$ & $0.10 \pm 0.0095$ \\
\hline +Cobaltous acetate & $0 \mathrm{mM}$ & $0.069 \pm 0.00153$ & $0.069 \pm 0.0005$ & $0.079 \pm 0.0005$ & $0.079 \pm 0.0005$ \\
\hline & $0.2 \mathrm{mM}$ & $-0.001 \pm 0.00005$ & $0.011 \pm 0.001$ & $0.058 \pm 0.001$ & $0.07 \pm 0.0005$ \\
\hline & $0.4 \mathrm{mM}$ & $-0.002 \pm 0.0001$ & $0.001 \pm 0.00011$ & $0.037 \pm 0.00057$ & $0.05 \pm 0.0015$ \\
\hline & $0.6 \mathrm{mM}$ & $-0.002 \pm 0.00011$ & $-0.001 \pm 0.00017$ & $0.033 \pm 0.00057$ & $0.04 \pm 0.001$ \\
\hline & $0.8 \mathrm{mM}$ & $-0.004 \pm 0.00001$ & $-0.002 \pm 0.00005$ & $-0.025 \pm 0.00057$ & $0.034 \pm 0.001$ \\
\hline & $1.0 \mathrm{mM}$ & $-0.006 \pm 0.00001$ & $-0.002 \pm 0.0001$ & $-0.023 \pm 0.00057$ & $-0.021 \pm 0.00057$ \\
\hline +SDS & $0.00 \mathrm{mM}$ & $0.069 \pm 0.00153$ & $0.069 \pm 0.0005$ & $0.079 \pm 0.0005$ & $0.079 \pm 0.0005$ \\
\hline & $0.2 \mathrm{mM}$ & $0.0686 \pm 0.00153$ & $0.069 \pm 0.0005$ & $0.079 \pm 0.0005$ & $0.079 \pm 0.0005$ \\
\hline & $0.4 \mathrm{mM}$ & $0.069 \pm 0.00153$ & $0.0688 \pm 0.0005$ & $0.079 \pm 0.0005$ & $0.079 \pm 0.0005$ \\
\hline & $0.6 \mathrm{mM}$ & $0.0688 \pm 0.00153$ & $0.069 \pm 0.0005$ & $0.0788 \pm 0.0005$ & $0.0789 \pm 0.0005$ \\
\hline & $0.8 \mathrm{mM}$ & $0.069 \pm 0.00153$ & $0.0687 \pm 0.0005$ & $0.079 \pm 0.0005$ & $0.0789 \pm 0.0005$ \\
\hline & $1.0 \mathrm{mM}$ & $0.069 \pm 0.00153$ & $0.069 \pm 0.0005$ & $0.0789 \pm 0.0005$ & $0.079 \pm 0.0005$ \\
\hline +Sodium Chromate & $0.00 \mathrm{mM}$ & $0.069 \pm 0.00153$ & $0.069 \pm 0.0005$ & $0.079 \pm 0.0005$ & $0.079 \pm 0.0005$ \\
\hline & $0.2 \mathrm{mM}$ & $-0.019 \pm 0.00057$ & $0.028 \pm 0.001$ & $0.056 \pm 0.00057$ & $0.073 \pm 0.00057$ \\
\hline & $0.4 \mathrm{mM}$ & $-0.02 \pm 0.001$ & $0.019 \pm 0.001$ & $0.039 \pm 0.00057$ & $0.056 \pm 0.001$ \\
\hline & $0.6 \mathrm{mM}$ & $-0.041 \pm 00057$ & $0.02 \pm 0.0005$ & $0.04 \pm 0.00$ & $0.051 \pm 0.00057$ \\
\hline & $0.8 \mathrm{mM}$ & $-0.053 \pm 00057$ & $-0.016 \pm 0.001$ & $-0.039 \pm 0.00057$ & $0.012 \pm 0.00057$ \\
\hline & $1.0 \mathrm{mM}$ & $-0.053 \pm 0.001$ & $-0.019 \pm 0.0015$ & $-0.039 \pm 0.00057$ & $-0.011 \pm 0.056$ \\
\hline +Cadmium sulfate & $0.00 \mathrm{mM}$ & $0.069 \pm 0.00153$ & $0.069 \pm 0.0005$ & $0.079 \pm 0.0005$ & $0.079 \pm 0.0005$ \\
\hline & $0.2 \mathrm{mM}$ & $-0.0019 \pm 0.00001$ & $0.019 \pm 0.00057$ & $-0.011 \pm 0.0005$ & $0.012 \pm 0.0013$ \\
\hline & $0.4 \mathrm{mM}$ & $-0.0029 \pm 0.00057$ & $0.01 \pm 0.00023$ & $-0.011 \pm 0.001$ & $0.010 \pm 0.00057$ \\
\hline & $0.6 \mathrm{mM}$ & $-0.012 \pm 0.001$ & $-0.011 \pm 0.00057$ & $-0.016 \pm 0.054$ & $-0.011 \pm 0.0005$ \\
\hline & $0.8 \mathrm{mM}$ & $-0.099 \pm 0.00057$ & $-0.013 \pm 0.0001$ & $-0.016 \pm 0.001$ & $-0.012 \pm 0.00017$ \\
\hline & $1.0 \mathrm{mM}$ & $-0.099 \pm 0.00057$ & $-0.042 \pm 0.00057$ & $-0.016 \pm 0.0015$ & $-0.012 \pm 0.0011$ \\
\hline
\end{tabular}

But effects with negative readings were observed for all the methods when the concertation raised to $0.6 \mathrm{mM}$. Specially, over $0.6 \mathrm{mM}$ of cobaltous acetate was given rise to shifting of the solution color from blue to bluish cloudy light (Figure $5 \mathrm{~A}_{4}$ ). Instead of been a cause for negative absorbance reading by Lowry and Modified Lowry methods, as low as $0.6 \mathrm{mM}$ of sodium chromate was also resulted for shifting of solution color to light green (Figure $5 A_{1}$ ). Up to $1 \mathrm{mM}$ of SDS was not shown any potential effect on the absorbance measurement by both original and modified Lowry and Biuret methods. In comparison, we found both the modified methods have comparable or better resistance to interferences by all the mentioned chemicals. Assay time for color development of the modified methods is compared with the original Lowry and Biuret methods (Table 3). Both the modified methods have shown development of deep blue color within 23 minutes. However, the original methods used an incubation time of 30 minutes for a light blue color development $[5,8]$. One of the expected hypotheses might be the fastest reaction formation capacity of nitrate ion to provide an easy access of copper ion for complex formation with the protein. The other hypothesis with ideal similarity of Pretty et al. [23] is when the concentration of $\mathrm{Cu}^{2+}$ reduced in the reagent, compactness of $\mathrm{Cu}^{2+}$ in the solution was also reduced and leaded to fastest movement of $\mathrm{Cu}^{2+}$ to form complex with the protein. On the basis, our modification confirms domination of rapidity over the original Lowry and Biuret methods. Reliability of the modified methods was employed based on daily and weekly percent coefficient of variations. For a reliability checkup, the determination of variation was performed with standard samples of BSA, Casein, Gelatin and Egg albumin. 


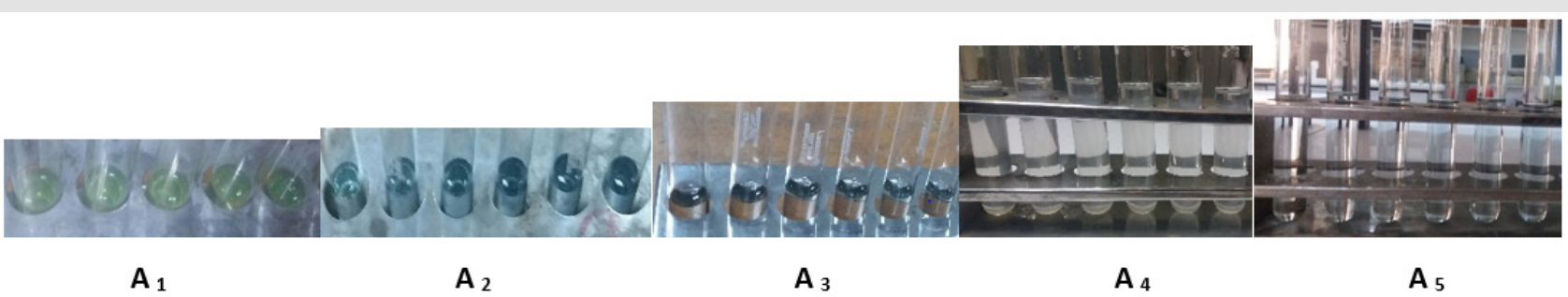

Figure 5: Photographs showing effect of Sodium chromate in Lowry Protein assay $\left(\mathrm{A}_{1}\right)$, Standard measurement of BSA by Modified Lowry assay $\left(A_{2}\right)$, effect of cadmium sulfate on the modified Lowry assay $\left(A_{3}\right)$, effect of cobaltous acetate on the Lowry assay $\left(\mathrm{A}_{4}\right)$ and effect of sodium sulfite on the modified Lowry assay $\left(\mathrm{A}_{5}\right)$.

Table 3: Effect of substitution of Copper nitrate by Copper sulfate on the incubation time of Lowry and Biuret methods.

\begin{tabular}{|c|l|c|}
\hline Assay method & Source of $\mathbf{C u}^{2+}$ & \multicolumn{1}{|c|}{ Incubation period(min) } \\
\hline \multirow{2}{*}{ Lowry } & Copper sulfate & 30 \\
\cline { 2 - 3 } & Copper nitrate & 23 \\
\hline \multirow{2}{*}{ Biuret } & Copper sulfate & 30 \\
\cline { 2 - 3 } & Copper nitrate & 23 \\
\hline
\end{tabular}

As shown briefly in Table 4, both the modified Lowry and Biuret methods were been recorded with low amounts for coefficient of variation. Even in comparison with the original methods reliability of the new methods reflect better or comparable results. DOC-TCA precipitation was conducted to purify protein samples from the recorded interferences by the interfering substances (Table 2). Most of the interfering substances were abolished by the precipitation. However, threshold amounts of Sodium chromate, Cadmium sulfate, and Sodium sulfite carried over from the precipitation were caused significant reduction of absorbance measurement by Lowry and modified Lowry methods (Table 5). So, effect of other interfering substances was efficiently avoided by DOC-TCA precipitation. Though, substances carried over from the precipitation caused significant interference, our farther study will continue on checking of additional purification methods for adequate abolishment of those substances. In comparison, after DOC-TCA precipitation, both the modified methods have shown dominated resistance over the original ones. Especially the modified Biuret method was manifested better resistance for threshold amounts of interfering substances which bypassed DOC-TCA precipitation.

Table 4: Daily and weekly based coefficient of variations for the standard and modified Lowry and Biuret methods.

\begin{tabular}{|c|c|c|c|c|c|c|c|c|}
\hline \multirow{2}{*}{ Protein } & \multicolumn{3}{|c|}{ Daily based coefficient of Variation (\%) } & \multicolumn{4}{c|}{ Weekly based coefficient of variation (\%) } \\
\cline { 2 - 9 } & Lowry & Mod. Lowry & Biuret & Mod. Biuret & Lowry & Mod. Lowry & Biuret & Mod. Biuret \\
\hline BSA & 0.91 & 0.86 & 0.95 & 0.90 & 0.85 & 0.80 & 0.91 & 0.87 \\
\hline Casein & 0.894 & 0.81 & 0.93 & 0.88 & 0.83 & 0.79 & 0.90 & 0.85 \\
\hline Gelatin & 0.90 & 0.87 & 0.93 & 0.89 & 0.87 & 0.81 & 0.91 & 0.88 \\
\hline Egg albumin & 0.892 & 0.82 & 0.91 & 0.871 & 0.87 & 0.81 & 0.89 & 0.84 \\
\hline
\end{tabular}

\section{Conclusion}

Hemi-Penta hydrated Copper nitrate-based modification of Lowry and Biuret methods resulted for a better validity and reliability with a reduction of assay time in both methods by 7 minutes. The modification also increased resistance of the methods for interferences by SDS, Tris buffer, Sodium sulfite, Cadmium sulfate, Sodium chromate, Cobaltous acetate and Tannic acid.

\section{Acknowledgments}

The chemicals required for this work were provided by Department of Medical Biochemistry, College of Health Sciences, and Addis Ababa University from the annual budget of the University allocated to the Departments. The authors sincerely thank Dr. Abebaye Aragaw (Department of Medical Physiology, College of Health Sciences, and Addis Ababa University) for his critical review of this manuscript.

\section{References}

1. Noble, James E, Marc JA, Bailey (2009) Quantitation of protein.Methods in enzymology, 463: 73-95.

2. Antharavally, Babu S, Krishna A Mallia, Priya Rangaraj, Paul Haney, et al. (2009) Quantitation of proteins using a dye-metal-based colorimetric protein assay. 2, Analytical biochemistry 385(2): 342-345. 
3. Krohn Randall I (2005) The colorimetric detection and quantitation of total protein. A-3I, Current protocols in toxicology 23.

4. Stoscheck, Christa M (1990) Quantitation of protein. [6] In Methods in enzymology 182: 50-68.

5. Lowry, Oliver H, Nira J Rosebrough, A Lewis Farr, Rose J Randall (1951) Protein measurement with the Folin phenol reagent. 193 265-275. Journal of biological chemistry, Vol. 193(1): 265-275.

6. EF Hartree (1972) Determination of protein: a modification of the Lowry method that gives a linear photometric response. 48.2 422. 2, 1977, Analytical biochemistry 48(2): 422.

7. Peterson, Gary LA (1977) simplification of the protein assay method of Lowry et al. which is more generally applicable. Analytical biochemistry 83(2): 346-356.

8. Gornall, Allan G, Charles J Bardawill, Maxima M David (1949) Determination of serum proteins by means of the biuret reaction Journal of biological chemistry 177(2): 751-766.

9. Bradford, Marion M (1976) A rapid and sensitive method for the quantitation of microgram quantities of protein utilizing the principle of protein-dye binding. 1-2, Analytical biochemistry 72(1): 248-254

10. Smith PK, R Il Krohn, GT Hermanson, AK Mallia (1985) Measurement of protein using bicinchoninic acid. 1, Analytical biochemistry 150(1): 76-85.

11. Compton, Steve J, Clive G Jones (1985) Mechanism of dye response and interference in the Bradford protein assay Analytical biochemistry 151(2): 369-374.

12. TH Ji (1973) Interference by detergents, chelating agents, and buffers with the Lowry protein determination, Analytical biochemistry 52(2): 517-521.

13. Xie, Qiushi, Gavin M, Burnell (1994) Interference of $\mathrm{Mg}^{+}$and $\mathrm{Ca}^{+}$ on protein determination with Lowry's method, Comparative Biochemistry and Physiology Part B: Comparative Biochemistry 107(4): 605-608

14. Shen, Yue-xiao, Kang Xiao, Peng Liang, Yi-wei Ma, et al. (2013) Improvement on the modified Lowry method against interference of divalent cations in soluble protein measurement. Applied microbiology and biotechnology 97: 4167-4178.

15. Vallejo, Carmen G, Rosario Lagunas (1970) Interferences by sulfhydryl, disulfide reagents and potassium ions on protein determination by Lowry's method. 1, s.l : Analytical biochemistry 36(1): 207-212.

16. Sapan, Christine V, Roger L, Lundblad, Nicholas C Price (1999) Colorimetric protein assay techniques. 2, Biotechnology and applied Biochemistry 29(2): 99-108.

17. Kresge, Nicole, Robert D, Simoni, Robert L Hill (2005) The most highly cited paper in publishing history: Protein determination by Oliver $\mathrm{H}$. Lowry. Journal of Biological Chemistry 280(28): e26-e28.

\section{ISSN: 2574-1241}

DOI: 10.26717/BJSTR.2021.39.006367

Yohannis Wondwosen. Biomed J Sci \& Tech Res

This work is licensed under Creative Commons Attribution 4.0 License

Submission Link: https://biomedres.us/submit-manuscript.php
18. Bensadoun, André, David Weinstein (1976) Assay of proteins in the presence of interfering materials. Analytical biochemistry 70(1): 241250.

19. Sapan, Christine V, Roger L Lundblad, Nicholas C Price (1999) Colorimetric protein assay techniques. Biotechnology and applied Biochemistry 29(2): 99-108.

20. Morton Richard E, Tracy A Evans (1992) Modification of the bicinchoninic acid protein assay to eliminate lipid interference in determining lipoprotein protein content. Analytical biochemistry 204(2): 332-334.

21. Brown, Rhoderick E, Kari L Jarvis, Kristi J Hyland (1989) Protein measurement using bicinchoninic acid: elimination of interfering substances. Analytical biochemistry 180(1): 136-139.

22. Lyubenova, Lyudmila, Hanif Bipuah, Ebenezer Belford, Bernhard Michalke, Barbro Winkler, et al. (2015) Comparative study on the impact of copper sulphate and copper nitrate on the detoxification mechanisms in Typha latifolia. Environmental Science and Pollution Research 22(1): 657-666.

23. Preety, Chauhan, Nidhi, Swati Sharma, Vinita Hooda (2018) Improved protein determination assays obtained after substitution of copper sulfate by copper oxide nanoparticles. Analytical biochemistry 547: 19-25.

24. Mohanapriya S, Senthilkumar, P, Sivakumar, S, Dineshkumar M, Subbhuraam CV (2006) Effects of copper sulfate and copper nitrate in aquatic medium on the restoration potential and accumulation of copper in stem cuttings of the terrestrial medicinal plant, Portulaca oleracea Linn Environmental monitoring and assessment 121(1-3): 233-244.

25. Lu Y, Fu TJ (2020) Performance of Commercial Colorimetric Assays for Quantitation of Total Soluble Protein in Thermally Treated Milk Samples,6, s.l: Food Analytical Methods 202 13(6): 1337-1345.

26. Zaguri M, Kandel S, Rinehart, SATorsekar, VR Hawlena D (2021) Protein quantification in ecological studies: A literature review and empirical comparisons of standard methodologies. s.l : Methods in Ecology and Evolution 12(7): 1240-1251.

27. Xie, Liyang, Randy L Wehling, Ozan Ciftci, Yue Zhang (2017) Formation of complexes between tannic acid with bovine serum albumin, egg ovalbumin and bovine beta-lactoglobulin.s.l : Food research international 102: 195-202.

28. Vallejo, Carmen G, Rosario Lagunas (1970) Interferences by sulfhydryl, disulfide reagents and potassium ions on protein determination by Lowry's method, Analytical biochemistry 36(1): 207-212.

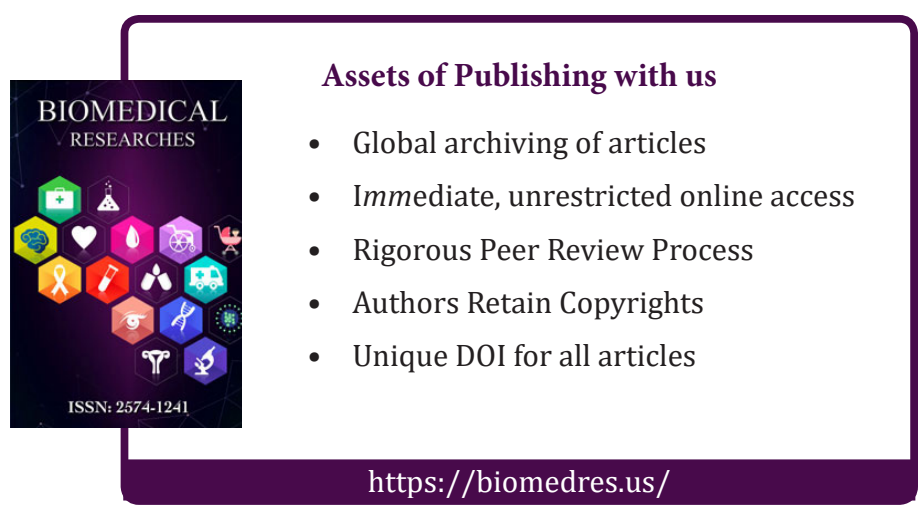

